\title{
Adaptive wetland management in an uncertain and changing arid environment
}

\author{
Rebekah Downard ${ }^{1}$, Joanna Endter-Wada ${ }^{1}$ and Karin M. Kettenring ${ }^{1}$
}

\begin{abstract}
Wetlands in the arid western United States provide rare and critical migratory bird habitat and constitute a critical nexus within larger social-ecological systems (SES) where multiple changing land-use and water-use patterns meet. The Bear River Migratory Bird Refuge in Utah, USA, presents a case study of the ways that wetland managers have created adaptive management strategies that are responsive to the social and hydrological conditions of the agriculture-dominated SES within which they are located. Managers have acquired water rights and constructed infrastructure while cultivating collaborative relationships with other water users to increase the adaptive capacity of the region and decrease conflict. Historically, water management involved diversion and impoundment of water within wetland units timed around patterns of agricultural water needs. In the last 20 years, managers have learned from flood and drought events and developed a long-term adaptive management plan that specifies alternative management actions managers can choose each year based on habitat needs and projected water supply. Each alternative includes habitat goals and target wetland water depth. However, wetland management adapted to agricultural return-flow availability may prove insufficient as population growth and climate change alter patterns of land and water use. Future management will likely depend more on negotiation, collaboration, and learning from social developments within the SES than strictly focusing on water management within refuge boundaries. To face this problem, managers have worked to be included in negotiations with regional water users, a strategy that may prove instructive for other wetland managers in agriculture-dominated watersheds.
\end{abstract}

Key Words: adaptive management; collaboration; Great Salt Lake, Utah; social-ecological systems; water policy; wetlands

\section{INTRODUCTION}

Freshwater scarcity is a growing, global problem (Postel 2000). The histories of arid and drought-prone regions of the world illustrate varying ecological and human responses to freshwater scarcity (Falkenmark 2013). Over the past two centuries, human adaptations in the arid western United States have depended on the establishment of water policies and engineered infrastructure to manage water scarcity for stationary settlement and economic security (Jackson et al. 2001). These human adaptations to aridity and drought, however, have often occurred at the expense of natural ecosystems. In particular, alterations of rivers in the western United States for irrigated agriculture, mineral development, and hydropower production have had significant negative effects on wetlands in the region (Dahl 2011). Climate change and population growth potentially pose even larger threats to wetlands because they will alter patterns of water use on rivers where wetland managers have adapted to agricultural-dominated water regimes and will increase the threat of serious drought and flooding (Knapp et al. 2008, Erwin 2009). Here, we examine how managers of the Bear River Migratory Bird Refuge in Utah, USA, have used adaptive management to face the uncertainty of a dynamic, drought-prone water supply and how the role they play in collaborative strategies at a critical wetland nexus within a larger social-ecological system (SES) can help them face a future of increased water scarcity and uncertainty.

Wetlands in the U.S. Intermountain West region are rare and critical habitat on international migratory bird flyways in a largely arid region (Evans and Martinson 2008). Maintaining wetland functions despite water scarcity is a management challenge with potential impacts to hundreds of bird species (Lemly et al. 2000, Tiner 2003). Irrigated agriculture has negatively affected wetlands through alteration of river hydrology, diversion of limited water supplies, increased pollution, and fragmentation of large wetland areas (Gordon et al. 2010, Brinson and Eckles 2011). Many remaining wetlands are managed by state and federal wildlife agencies under the requirements of federal water quality and wildlife protection laws (in particular, the Clean Water Act and Migratory Bird Treaty Act) and in accordance with state and local water policies. In this region, wetlands are inextricably linked to irrigated agriculture, which uses the majority of water supplies, but which also has created new wetlands near canals and reservoirs where irrigation return flow (Box 1) is now the primary summer water source for some wetlands (Peck and Lovvorn 2001, Peck et al. 2004). Changes to current patterns of agricultural water use, including increased irrigation efficiency and transfers of irrigation water to other uses, will decrease the water available to such irrigation-dependent wetlands (Poff et al. 2007, Downard and Endter-Wada 2013, Sueltenfuss et al. 2013).

Box 1. Prior appropriation water law terminology.

Adjudication - a court proceeding to determine all the rights to use water from a water source or within an area.

Beneficial use - the purposes for which water can be legally diverted and/or used, consistent with state law, and specified in a water right.

Diligence and underground water rights - in Utah, these are based on claims made during the adjudication process for waters that have traditionally been used by a water user; diligence claims are rights to waters that had been used prior to 1903, and underground water claims are rights to underground water that had been used prior to 1935 . 
Duty of water-a court-determined annual quantity of water needed to satisfy the irrigation water requirements of crops in a particular area, generally measured as acre-feet of water per acre per year (acft $\mathrm{ac}^{-1} \mathrm{yr}^{-1} ; 1 \mathrm{acft}=1233 \mathrm{~m}^{3}$ ).

Federal reserved water rights - water rights created under federal law for lands reserved by the federal government (e.g., wildlife refuges, national parks, forests, or Indian reservations); the government claims reserved water rights sufficient to fulfill the primary purposes of those lands; these water rights have priority dates based on the date the land reserve was established.

Place of use - the area where a water right can be used, specified in a water right.

Prior appropriation - the dominant water right allocation policy in the arid western United States; water rights are granted on a "first in time, first in right" priority basis, water shortages are not shared, and users must continually put their rights to established beneficial uses or risk losing them.

Return flow - the portion of diverted water that is not consumptively used (through transpiration, evaporation, or percolation) and that returns to a water body; it is specific to beneficial uses, methods of application, and climate.

Wetlands are frequently characterized as transitional systems (i.e., ecotones) because they lie at the boundary of dry upland and deeper aquatic ecosystems (Mitsch and Gosselink 2007). Within SESs, i.e., the linked natural resources, resource managers and users, infrastructure, and institutions of an area (Berkes and Folke 1998, Anderies et al. 2004), wetlands lie at an important nexus between transitioning resource-use states and institutions (Walker et al. 2004). The wetland nexus, a critical series of linkages within an SES, can take a number of forms. As a political nexus, wetlands lie at the intersection of multiple policies (i.e., wildlife, water quantity, and water quality) that complicate management. As a physical nexus, wetlands often lie at the interface of land and water and/or at the interface of different water bodies such as rivers and lakes, which makes water allocation and management challenging (Adler 2005). As a land use nexus, wetlands are often at the boundary of shifting landscape patterns such as areas transitioning from agricultural to urban land uses, which drive the changes threatening wetlands. The wetland nexus is dynamic and shifts according to annual hydrological patterns, policy changes, technological advances in water use, and changing population demographics. Thus, management of wetlands requires an understanding of regional social and ecological dynamics and the linkages within SESs (Welsh et al. 2013). From a functional point of view, wetland boundaries are dynamic and often unclear, especially when management of migratory (wildlife) and flowing (water) resources is considered. Migratory resources can introduce effects from far beyond a wetland's designated boundaries (Duffy and Kahara 2011).

Hydrology is the defining feature of a wetland. Wetland hydrology is naturally dynamic, and periodic drying or drought is an important part of the wetland hydroperiod (Euliss et al. 2008, Smith et al. 2008). However, severe drought increases the likelihood of negative ecological consequences, including invasion of undesirable plant species and decreased growth and germination of desirable species (Bunn and Arthington 2002, Zedler and Kercher 2005). The point at which drought causes negative ecological effects is often unknown, but is likely specific to region and wetland type. The combination of incomplete knowledge of wetland hydrology and ecology, the unpredictability of water supplies in arid regions, and the changes occurring outside wetland boundaries lead to a high degree of uncertainty for wetland managers trying to maintain resilient wetland habitat (Brugnach et al. 2008). Climate changes leading to more extreme and frequent drought and flooding could further stress vegetation and create greater uncertainty about threats to wetlands and the effectiveness of various management options (Oki and Kanae 2006, Acreman et al. 2009). Adaptive water management is a promising approach for managing wetlands under conditions of uncertainty in arid regions.

Practitioners of adaptive management (AM) use the best available scientific information to formulate resource management practices, monitor pre-defined environmental feedback variables, and make subsequent decisions based on what they learn from monitoring (Holling 1978, Porzecanski et al. 2012). The goal of $\mathrm{AM}$ is to protect the resilience and adaptive capacity of ecosystems, defined as the ability to recover from disturbance and cope with existing and future stresses (Walker and Meyers 2004). Adaptation is particularly important for managers of wetlands in the lowest portions of watersheds, where large, long-term landscape changes have created novel, heavily modified ecosystems that will never meet traditional ecosystem management goals (Zedler et al. 2012). Monitoring and learning from the effects of ongoing management activities is often neglected in AM (Gunderson 1999) but is particularly critical in the Intermountain West, where wetlands are rare, water shortages are frequent, and the consequences of management are generally more significant. Learning is also important in arid regions because much is still unknown about the water needs of wetlands, particularly concerning possible thresholds when increasingly severe droughts decrease the resilience of wetland systems (Gunderson et al. 2006).

AM that recognizes the linkages and dynamics between natural and social processes within SESs can increase the resilience and adaptive capacity of such systems by identifying multiple drivers of change occurring over longer time scales and larger spatial extents. Collaboration in AM, through knowledge sharing and collective action among users who are interdependent on common resources, increases learning by bringing multiple perspectives to bear on the same problem, thereby decreasing uncertainty and increasing adaptive capacity (Olsson et al. 2004, Hahn et al. 2006, Endter-Wada et al. 2009). However, collaboration becomes more challenging as population growth increases the number of parties in collaborative processes and climate change tightens the linkages in SESs by shortening the response time between changes in ecological components and reactions in social components (and vice versa; Walker et al. 2002, Folke 2006). Contextualized case studies are one way to study successful adaptation and collaboration in SESs and identify practices and lessons applicable in other regions (Young et al. 2006, Endter-Wada and Blahna 2011).

The Bear River Migratory Bird Refuge (BRMBR) in Utah, USA, provides one such case study with which to examine how AM has been applied successfully to a wetland complex with an uncertain and dynamic water supply. This wetland refuge lies at the shifting nexus of water and land-use patterns within the Great Salt Lake 
Fig. 1. Maps showing the locations of (a) the Bear River Migratory Bird Refuge within the Great Salt Lake social-ecological system, and (b) the lower Bear River watershed.
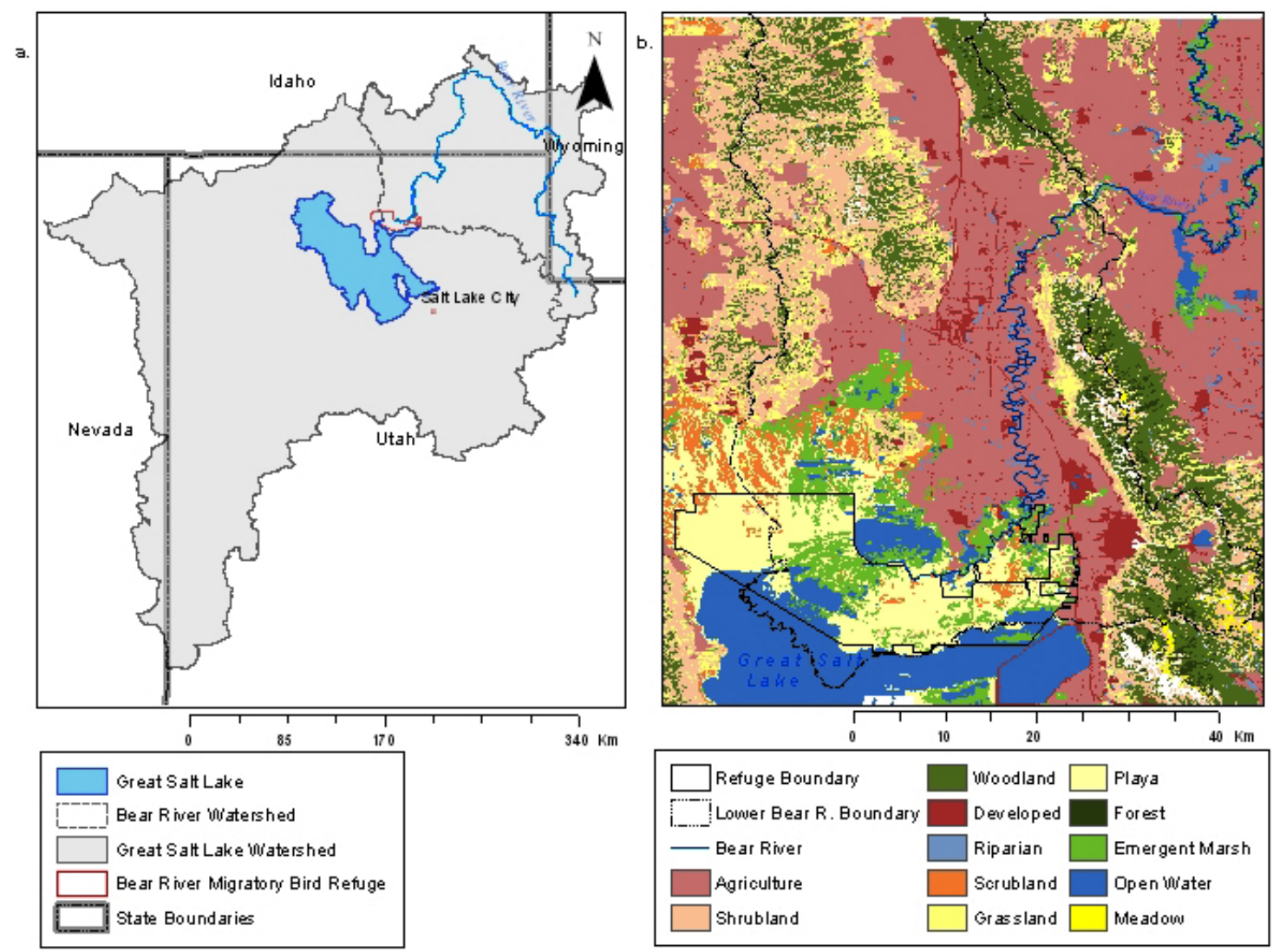

SES. The objectives of this case study are: (1) to identify historical and current management challenges at this wetland nexus; (2) to analyze adaptation to the ecological and social management challenges of the Bear River that are characteristic of wetland management in an arid region; and (3) to identify the generalizability of potential strategies for future wetland management in transitioning SESs. The Bear River watershed and wetlands of BRMBR are representative of other arid and semiarid watersheds, where rivers have been extensively diverted for agricultural uses and changes to hydrology have inextricably linked wetlands to irrigated agriculture. The lessons about effective wetland management in such SESs are applicable to wetlands throughout the region and in other agriculturedominated watersheds.

\section{METHODS}

\section{Study area}

BRMBR, established in 1928, is a 30,000 ha wetland complex managed by the U.S. Fish and Wildlife Service (USFWS) at the delta where the Bear River enters the northeast arm of Great Salt Lake (GSL) in Utah, USA (Fig. 1). The GSL is a hyper-saline terminal lake fringed by $>161,000$ ha of freshwater and brackish wetlands that support millions of birds on the Central and Pacific migratory bird flyways every year (Aldrich and Paul 2002, Ivey and Herziger 2006). The Bear River provides $60 \%$ of the annual freshwater inputs for the GSL; it is a heavily-managed, droughtprone river that flows for $800 \mathrm{~km}$ through the states of Idaho, Utah, and Wyoming, crossing state boundaries five times. The climate of the Bear River basin is semi-arid; the basin receives 54 $\mathrm{cm}$ of precipitation annually, primarily in the form of winter snow (Utah Water Research Laboratory 2012). Stream flow is driven by snow pack that accumulates in the Rocky Mountains and is stored in reservoirs during spring runoff for controlled release during the irrigation season. Annual stream flow is naturally highly variable and unpredictable on an interannual basis. Regional climate change models forecast higher rates of evapotranspiration, more frequent and severe droughts and floods, and a shift to precipitation in the form of rain rather than snow for the Intermountain West (Lundquist et al. 2009, Mote 2009, Jin et al. 2011). These forecasted changes will present serious challenges for a water management system engineered to capture snowmelt. Water users have dealt with the natural hydrological variability in this basin in the past by employing interannual water storage and release strategies that may not be compatible with future changes in precipitation related to climate change and urbanizing patterns of water demand that are year-round rather than seasonal.

Water in the state of Utah is allocated under the rules and institutional structures of prior appropriation, which is codified 
in state law and modified through interstate compacts, court adjudications, reservoir operation agreements, and water development plans (Box 1). Agriculture is the primary use of Bear River water, accounting for $96 \%$ of river diversions (Utah Division of Water Resources 2004). Irrigation in the Bear River basin began in 1860, and subsequent water development to support agriculture and hydropower production extensively dried the river's delta with the GSL, exacerbating outbreaks of avian botulism. Local concern and petitions led the U.S. Congress to designate the remaining wetlands as a national migratory bird refuge in 1928. Despite a long history of water rights acquisition and development, the Bear River basin remains one of the few basins in the West open to new appropriations with proposed water development projects (Utah Division of Water Resources 2004). Rapid population growth is currently driving the transition of land and water use from irrigated agriculture to municipal development, which may have profound consequences for the ways in which Bear River water is distributed (Denton 2007).

\section{Semi-structured interviews}

Data for our case study were gathered from multiple sources, including semi-structured key informant interviews, water rights records, management documents, and historical archives. Key informant interviews were conducted in 2009-2010 with current and retired wetland managers, regional water rights experts, members of national conservation groups, and staff of wetland research agencies. Initial key informant interviewees were identified and then additional interviewees were selected through reputational and snowball sampling. Interview protocols guided respondents through discussion of wetland water supply sources, refuge water needs, water-related management activities, water rights acquisition strategies, and interviewees' perceptions of drought, water controversies, and potential cooperation in water management. Interviews were conducted under a protocol approved by Utah State University's Institutional Review Board and were recorded, transcribed, and analyzed for themes and insights regarding wetland water management in an SES (see Appendix 1 for interview protocol).

\section{Archival research}

Wetland water needs and supply were determined based on searches of water rights from the Utah Division of Water Rights (2011) online database, U.S. Geological Survey (2014) stream flow gages, and historical watershed and refuge documents. Water rights data were verified and supplemented by information provided in key-informant interviews and complemented by stream gauge data, which identified the reliability of formal rights to provide practical access to water throughout the year. Legal, historical, and management documents identified important developments in basin-wide drought adaptation strategies, as well as current management approaches, concerns, and adaptations. Utah State University's Bear River Watershed Historical Digital Collection provided access to a large collection of archival documents.

\section{RESULTS}

Our research uncovered important insights into two major components of AM at BRMBR: (1) development of water management capacity through water rights acquisition and infrastructure construction; and (2) collaboration with other water users to increase adaptive capacity and decrease conflict.
We discuss each of these components and how they work within the shifting wetland nexus of the GSL SES.

\section{Adaptive water management: managing wetlands in an agriculture-dominated region}

At BRMBR, wetland water needs, water rights acquisition, and water management are determined by migratory bird use. Monthly water needs for the wetlands of the Bear River delta were determined through models built by the Utah Division of Water Rights (UDWRi) and the USFWS to determine the volume of water required to meet the needs of waterfowl production, which is the beneficial use of water in the delta. State models developed in the 1960s defined "need" as the minimum amount of water required to maintain wetlands "in a productive state for the raising of waterfowl and hunting purposes" and calculated the amount of water needed to manage salinity and water loss due to evapotranspiration for desirable plant species (i.e., Schoenoplectus spp. and Stuckenia spp.; Christiansen and Low 1970:83). A more complex model put together by the USFWS during the 1990s lower Bear River adjudication process was identified by refuge managers as a critical development in their water management planning. This model included detailed information on monthly bird use and habitat requirements, daily evapotranspiration and canal seepage losses, water depth requirements for multiple habitat types, and water for flushing wetlands. According to the water rights for BRMBR, wetland water needs are highest from March to September, which incorporates both the wetland growing season and a period of time to use excess stream flow to fill wetland units (Table 1). Other ecological water needs in the GSL delta ecosystem include the volume of water necessary to maintain water quality parameters in wetlands related to nutrients and toxins and to protect a minimum elevation for the GSL. However, both of these water needs remain unquantified and are not accounted for in any water rights allocations. Thus, impaired water quality and fluctuating GSL shorelines are also management challenges at BRMBR.

BRMBR managers began applying for water rights upon refuge establishment in 1928 and have acquired a portfolio of 28 water rights through a multi-faceted and sustained effort (Table 2). The foundational water right for the refuge is for year-round diversion of 1000 cubic feet per second ( $\mathrm{cfs} ; 1 \mathrm{cfs}=0.0283 \mathrm{~m}^{3} / \mathrm{s}$ ) from the Bear River for waterfowl production. That right has a 1928 priority, and managers have long recognized that it is a "junior right" compared to the rights of nearby water users, the majority of whose rights have priority dates between 1890 and 1909 (Utah Division of Water Rights 2005). Thus, the refuge's rights are likely to be curtailed during the dry periods of the year when water is delivered to fulfill the senior rights. Working with UDWRi, refuge managers have enhanced this foundational water right by filing diligence and underground water claims on other water sources that have traditionally flowed through the refuge. The USFWS also purchased land and water rights near the refuge to protect grassland habitat that buffers the refuge from encroaching suburban development. Based on wetland water need models, the state of Utah granted BRMBR wetlands a higher "duty of water" for their rights than is allocated to nearby irrigated agriculture $\left(21,336 \mathrm{~m}^{3} \mathrm{ha}^{-1} \mathrm{yr}^{-1}\left[7 \mathrm{acft} \mathrm{ac}^{-1} \mathrm{yr}^{-1}\right]\right.$ for wetlands versus 12,192 $\mathrm{m}^{3} \mathrm{ha}^{-1} \mathrm{yr}^{-1}$ [4 acft ac $\mathrm{yr}^{-1}$ ] for agriculture; $1 \mathrm{acft} \mathrm{ac}^{-1} \mathrm{yr}^{-1}=$ $3053.11 \mathrm{~m}^{3} \mathrm{ha}^{-1} \mathrm{yr}^{-1}$ ), which means that refuge managers can apply more water per area to their wetlands than can agricultural 
irrigators, when water is available. The refuge's portfolio of water rights grants access to multiple sources, but water from the Bear River represents the primary supply for the refuge, accounting for $95 \%$ of the amount of water in the refuge's portfolio when considering the total annual volume of water the refuge has acquired from all water sources (Table 2). The "place of use" for these water rights ends at the southern-most dike of the refuge, leaving no legal water supply for the delta wetlands that are outside the dike system but still within the refuge's boundary. During the height of the irrigation season, BRMBR and associated GSL wetlands are entirely dependent on what water remains in the Bear River after upstream irrigators have used their rights.

Table 1. Calculated water needs for the wetlands of Bear River Migratory Bird Refuge (based on water rights from Utah Division of Water Rights 2011) and total monthly discharge of the Bear River upstream of the refuge (U.S. Geological Survey 2012). All units are in acre-feet $\left(1\right.$ acre-foot $\left.=1233 \mathrm{~m}^{3}\right)$.

\begin{tabular}{lrrrrr}
\hline \hline & & \multicolumn{4}{c}{ Bear River discharge } \\
\cline { 3 - 6 } Month & Water & $\begin{array}{r}\text { Recent } \\
\text { notable }\end{array}$ & $\begin{array}{r}\text { Study year } \\
(2009)\end{array}$ & $\begin{array}{r}\text { Recent } \\
\text { notable } \\
\text { flood }\end{array}$ & $\begin{array}{r}2000-2011 \\
\text { average }\end{array}$ \\
& & & & $(2011)$ & \\
\hline January & 5938 & 53,457 & 63,746 & 80,931 & 74,438 \\
February & 8202 & 59,457 & 52,360 & 71,517 & 66,536 \\
March & 61,380 & 96,021 & 117,885 & 148,683 & 106,091 \\
April & 59,400 & 65,281 & 155,784 & 230,503 & 129,499 \\
May & 61,733 & 24,895 & 158,323 & 326,623 & 118,303 \\
June & 35,842 & 29,911 & 180,320 & 325,453 & 84,431 \\
July & 56,978 & 2644 & 15,358 & 151,282 & 19,177 \\
August & 40,868 & 2874 & 8797 & 84,049 & 12,738 \\
September & 60,072 & 7825 & 15,475 & 82,771 & 21,280 \\
October & 28,800 & 33,206 & 58,809 & 120,736 & 44,771 \\
November & 10,331 & 44,353 & 61,606 & 131,942 & 54,897 \\
December & 1997 & 64,940 & 59,616 & 106,891 & 65,184 \\
Total & 431,542 & 484,865 & 948,079 & $1,861,380$ & 797,346 \\
& & & & & \\
\hline
\end{tabular}

Discharge of the Bear River above BRMBR is highly variable, both between seasons and between years, making drought and flooding common and water management challenging. At the U. S. Geological Survey gauge at Corinne, Utah, just upstream of the refuge boundary, discharge increases throughout the spring months as mountain snowpack melts, usually peaking in June before falling precipitously during the subsequent summer months (Table 1). Managers report that in most years the refuge is operating at a water deficit during the summer, which coincides with the irrigation season as well as the wetland vegetation growing season, and $75 \%$ of the wetlands in the refuge go dry (Fig. 2). However, during flood years, the refuge receives far more water than it needs, which presents a threat to freshwater wetlands, as hypersaline waters of the GSL rise, and to the dikes and buildings on the refuge. To adapt to the dual challenges of drought and flooding, BRMBR managers designed water management infrastructure and developed management plans aimed at keeping wetland habitat growing during the summer months when water is scarce.

From 1928 to 1935 , managers constructed a system of canals and dikes that enabled them to divert and impound Bear River water within wetland units on the refuge when it was available in the spring and to draw it down slowly during the dry summer months. Historical documents and interviews with wetland managers highlight what a showcase system this infrastructure represented. The infrastructure was also used as a model for other refuges in the region. The alterations changed the area from a flow-through delta that water from the Bear River could no longer support to a series of shallow impoundments that disconnects the river from the lake in most years. The original infrastructure was destroyed during GSL flooding in the early 1980s, and managers rebuilt the system a decade later based on what they had learned from the previous 50 years of water management. In this second phase of dike construction, they included even more wetland units, which can be filled and drained independently, and a bypass canal to shunt unneeded water to the Great Salt Lake, thereby increasing the management capability. Currently, three canals deliver water to 26 separate units divided by $>155 \mathrm{~km}$ of dikes (Fig. 3 ). Through this system, managers maintain multiple types of wetland habitat, including permanently inundated, open water ponds, emergent marshes, and temporarily flooded playas that together serve the diverse needs of migratory birds.

Fig. 2. Ratio of Bear River discharge to the water needs of the Bear River Migratory Bird Refuge during a drought year (2004), the study year (2009), and a flood year (2011). Shaded area indicates the growing season for wetland plants.

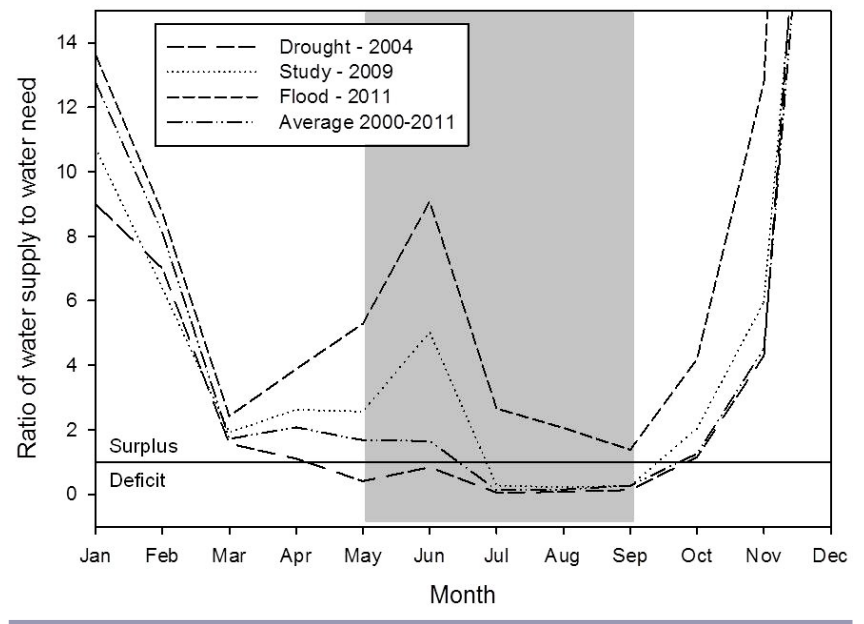

The variety of habitat types at BRMBR support $>200$ bird species, and BRMBR managers have developed a long-term AM plan based on the needs of 16 priority bird species that represent waterfowl, shorebirds, and colonial nesting birds (Olson et al. 2004, Olson 2009). The AM plan was developed through collaboration with regional wildlife managers and scientists, who researched what bird species the refuge supported within the larger Intermountain West region and the habitat needs of those species (Olson et al. 2004). The goal of the long-term plan is to guide structured decision-making processes for future years by providing multiple alternatives to choose from based on annual management objectives, needs, and constraints (Allen et al. 2011). The long-term plan specifies five management alternatives focused on maintaining salinity, water clarity, aquatic vegetation community composition, invertebrate abundance, or protecting levee structures; each year, an alternative and objectives for 
Table 2. Water rights held by the U.S. Fish and Wildlife Service for use at the Bear River Migratory Bird Refuge. Data were extracted from the Utah Division of Water Rights (2012) online database and verified through key-informant interviews.

\begin{tabular}{|c|c|c|c|c|c|c|}
\hline Claim & Claim number & Claim priority & Flow $(\mathrm{cfs}) \dagger$ & Volume (acft/yr) & Water source & Beneficial use \\
\hline \multirow[t]{8}{*}{$\begin{array}{l}\text { Applications to } \\
\text { appropriate }\end{array}$} & $29-980$ & 1907 & 0.5 & 70.7 & Surface drains & $\begin{array}{l}\text { Irrigation, } \\
\text { stockwater }\end{array}$ \\
\hline & $29-1014$ & 1928 & 1000.0 & $425,771.0$ & Bear River & Waterfowl habitat \\
\hline & $29-1165$ & 1955 & $<0.1$ & 0.4 & $\begin{array}{l}\text { Underground well, } \\
\text { perry }\end{array}$ & Stockwater \\
\hline & $29-1330$ & 1961 & 0.1 & $<0.1 \S$ & Underground well & Stockwater \\
\hline & $29-3668$ & 1991 & 3.71 & 2666.3 & Salt Creek & $\begin{array}{c}\text { Wildlife, fish } \\
\text { culture, irrigation }\end{array}$ \\
\hline & 29-3824 & 1995 & 1.0 & 40.0 & Underground drain & Wildlife \\
\hline & $29-3825$ & 1995 & 1.0 & 4.0 & $\begin{array}{c}\text { Stauffer-Packer } \\
\text { Spring }\end{array}$ & Wildlife \\
\hline & $29-1637$ & 1997 & 2.0 & $500.0_{1}^{1}$ & $\begin{array}{c}\text { Surface water, } \\
\text { underground } \\
\text { drains }\end{array}$ & $\begin{array}{l}\text { Irrigation, } \\
\text { stockwater }\end{array}$ \\
\hline \multirow[t]{11}{*}{ Diligence claims } & $29-3172$ & 1860 & 1.0 & 218.0 - & $\begin{array}{l}\text { Stauffer-Packer } \\
\text { Spring }\end{array}$ & Irrigation \\
\hline & $29-973$ & 1869 & 2.4 & $283.7 \S$ & Unnamed stream & $\begin{array}{c}\text { Wildlife, irrigation, } \\
\text { stock }\end{array}$ \\
\hline & $29-936$ & 1870 & 3.1 & 192.79 & Dan Walker Spring & Irrigation \\
\hline & $29-937$ & 1870 & 0.6 & 27.89 & $\begin{array}{l}\text { Perry Spring } \\
\text { Stream }\end{array}$ & Irrigation \\
\hline & $29-2622$ & 1880 & $<0.1$ & - & $\begin{array}{c}\text { Unnamed spring } \\
\text { stream }\end{array}$ & Stockwater \\
\hline & $29-1697$ & 1880 & 1.0 & 51.2 & $\begin{array}{c}\text { Unnamed spring } \\
\text { stream }\end{array}$ & $\begin{array}{l}\text { Irrigation, } \\
\text { stockwater }\end{array}$ \\
\hline & $29-3060$ & 1881 & 1.0 & $273.6 \S$ & Unnamed spring & Irrigation \\
\hline & 29-1919 & 1896 & 2.4 & $326.5 \S$ & Unnamed stream & $\begin{array}{l}\text { Irrigation, stock, } \\
\text { wildlife }\end{array}$ \\
\hline & $29-3157$ & 1902 & $<0.1$ & $0.3 \S$ & Unnamed stream & Stockwater \\
\hline & $29-3485$ & 1902 & 15.9 & $11,128.9$ & Bear River & Waterfowl habitat\# \\
\hline & $29-3698$ & 1902 & $4.8_{1}^{1}$ & 2000.0 & Bear River & Irrigation\# \\
\hline \multirow[t]{8}{*}{$\begin{array}{l}\text { Underground water } \\
\text { claims }\end{array}$} & $29-951$ & 1869 & 1.0 & 60.29 & $\begin{array}{c}\text { Perry Spring } \\
\text { Stream }\end{array}$ & $\begin{array}{l}\text { Irrigation, } \\
\text { stockwater }\end{array}$ \\
\hline & $29-3061$ & 1870 & $<0.1$ & 0.2 & $\begin{array}{c}\text { Underground water } \\
\text { drain (open) }\end{array}$ & Stockwater \\
\hline & $29-1915$ & 1885 & 1.5 & 171.4 & $\begin{array}{l}\text { Underground water } \\
\text { drain }\end{array}$ & Irrigation \\
\hline & $29-1916$ & 1885 & 2.0 & 109.7 & $\begin{array}{c}\text { Underground water } \\
\text { drain }\end{array}$ & Irrigation \\
\hline & $29-1914$ & 1887 & 3.0 & 147.69 & $\begin{array}{l}\text { Underground water } \\
\text { drain }\end{array}$ & Irrigation \\
\hline & $29-768$ & 1900 & 1.6 & 232.0 - & $\begin{array}{l}\text { Underground water } \\
\text { drain }\end{array}$ & Irrigation \\
\hline & $29-769$ & 1900 & 1.1 & 189.19 & $\begin{array}{c}\text { Underground water } \\
\text { drain }\end{array}$ & $\begin{array}{l}\text { Irrigation, } \\
\text { stockwater }\end{array}$ \\
\hline & $29-770$ & 1920 & $<0.1$ & 7.0 & Underground well & Stockwater \\
\hline \multirow[t]{2}{*}{ Decreed claims } & $29-1450$ & 1896 & 7.4 & 469.2 & East Slough & Irrigation \\
\hline & $29-3484$ & 1896 & 45.0 & $32,579.1$ & Black Slough & Irrigation, wildlife \\
\hline Total & & & & $462,535.6$ & & \\
\hline
\end{tabular}

$\dagger 1$ cubic-foot $/$ second $(\mathrm{cfs})=0.0283 \mathrm{~m}^{3} / \mathrm{s}$.

$\$ 1$ acre-foot (acft) $=1,233 \mathrm{~m}^{3}$.

$\S$ Volume calculated based on a proportion of a larger group of rights or a portion of rights used for a beneficial use.

'Flow calculated from rights measured in acre-feet (number of $\mathrm{cfs} \times 1.9835$ ).

qVolume calculated based on acreage (number of acres $\times 4$ [duty of water for irrigation]).

\#Rights are only available for use during high flow periods: May 1-June 15 and September 15-November 30.

enactment are chosen for each wetland unit on the refuge based on the outcomes of the previous year's actions and the current year's constraints (Olson et al. 2004). Water depth goals for each unit are set annually based on snow pack and spring runoff predictions. Wetland units are prioritized for water distribution within the refuge based on which are supporting the most priority 
Fig. 3. Water management infrastructure and the wetland types it supports at the Bear River Migratory Bird Refuge. Water rights "place of use" ends at the southernmost dike in the refuge. Diversions in the eastern portion of the refuge are primarily diligence and underground water claims. Bear River water rights comprise the bulk of diversions for the main refuge.

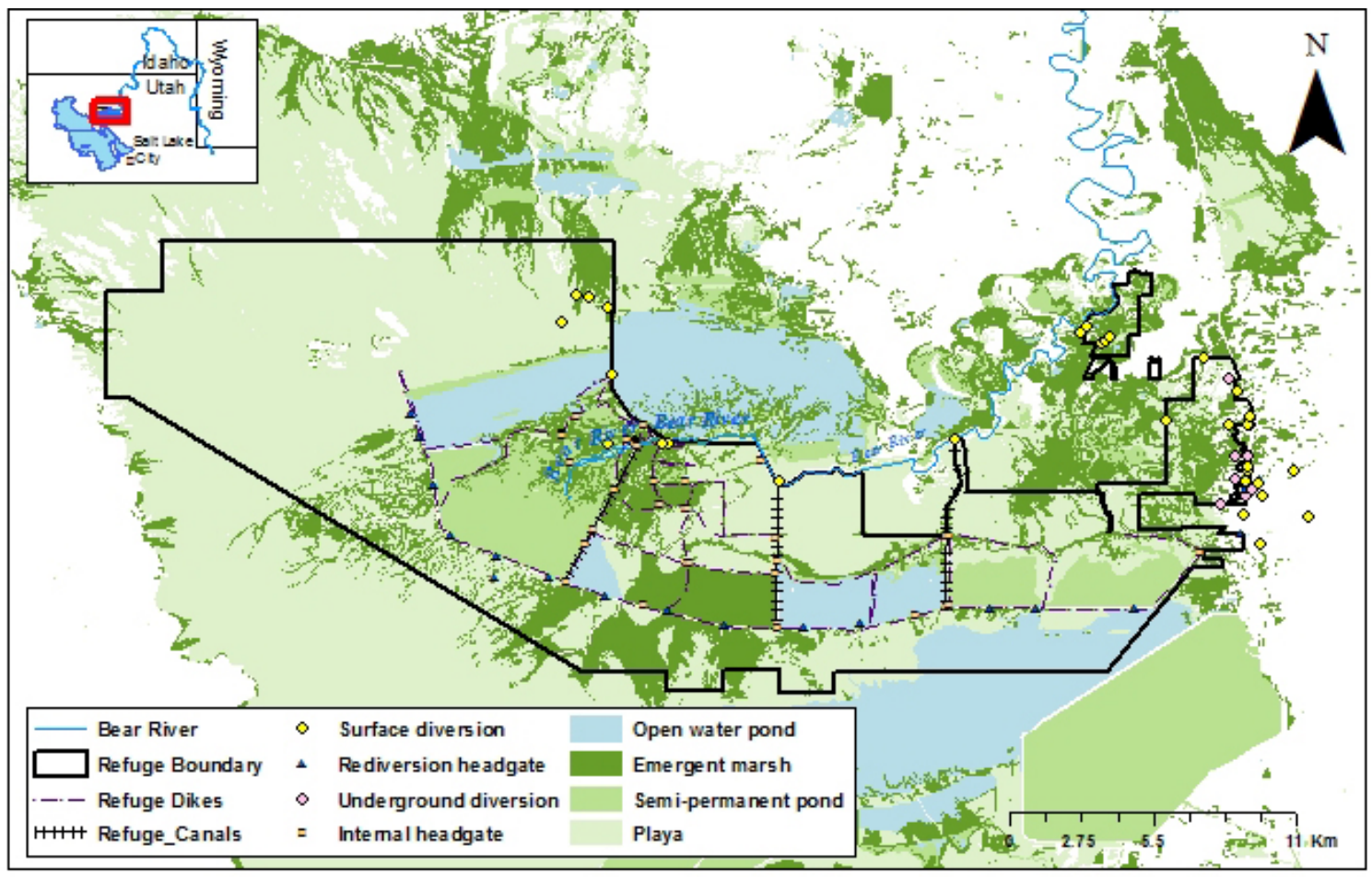

bird species. This AM strategy assumes that the best way for BRMBR to maximize migratory bird habitat is to promote the most productive submerged and emergent wetland communities by managing water at specified water depths. Within the growing season, managers monitor bird use to ensure water is available where wildlife needs it; if conditions deviate from predictions or if special management needs arise (e.g., dike repair), managers can move water according to observed conditions (for examples, see Olson 2006, 2007, 2008). Refuge managers then monitor habitat response through measurement of submerged and emergent vegetation cover, aquatic species diversity, soil salinity, water depth at wetland outlets, and weekly bird surveys (Olson 2006). By facilitating the collection of data on water availability and responses of vegetation and birds, monitoring has the potential to address some of the uncertainty about how bird populations are affected by drought and when drought decreases the resilience of wetland vegetation. Wetland resilience is maintained through water management that prevents rapid, severe water-level drawdown and through planning that minimizes the number of consecutive years an area will experience drought. Management plans and results are shared with the community of water users and people interested in the refuge's management. Refuge planning processes incorporate public input, thereby encouraging community participation and support for the refuge's water use and facilitating social learning from other Bear River water users' experiences.

\section{Adaptive water management: learning from controversy and collaboration}

As the water right user at the end of the Bear River, BRMBR wetlands are affected by nearly all upstream changes to water quantity and quality. For most of the refuge's history, managers have worked to buffer these wetlands and the functions they perform from the effects of irrigated agriculture. However, a significant portion of management in the last 20 years has been focused on adaptation to changes in the broader GSL SES in which the refuge is embedded. The understanding that most of the water remaining in the Bear River during the summer months is return flow from upstream irrigation creates incentives to communicate with other users about their water use plans and the refuge's needs during this critical season. Dependence on return flow leaves wetlands vulnerable to agricultural changes that would alter water-use patterns, such as increased irrigation efficiency or taking land out of production for residential development. Social adaptation has involved actively identifying ways to protect or enhance not only the refuge's water supply, but to enhance collaboratively the water quality and quantity of the lower Bear River region and Bear River watershed as a whole. This process has not been without controversy, and managers have learned about the importance of cooperation through both positive and negative interactions with the community of lower Bear River water users.

During the early 1990s, while managers were rebuilding flooded refuge infrastructure, an initial effort was made to secure a federal 
reserved water right claim for the refuge. The reserved rights claim was for $1.2 \times 10^{8} \mathrm{~m}^{3}(100,000 \mathrm{acft})$ of water during July and August that is covered in BRMBR's state water rights for $28.3 \mathrm{~m}^{3} / \mathrm{s}(1000$ cfs) flow from the Bear River but is not met by actual supply in the river. However, the date of refuge establishment would be the priority date for federal reserved water rights, and a 1928 priority is still junior to other users, making securing additional water unlikely. The reserved right claim was dropped quickly because of its impracticality, but the process increased tension between the Refuge and the state of Utah, which holds title to a portion of lands the refuge manages, and other water users in the area who perceived the process as an intrusion of the federal government on state water authority. Refuge managers have also supported a new dam and reservoir on the Bear River, where they could store some of the surplus spring water supply for use during the dry summer, an unusual position for the USFWS but a significant long-term strategy for this particular refuge. When a dam was proposed in a rural community north of BRMBR, refuge managers sought a $50 \%$ share in the reservoir. However, the reservoir was never built, resulting in lost time and effort and more tension with community members who opposed the reservoir. Managers learned from these mistakes and adjusted their focus to managing the wetlands with available water and working to protect that supply through state-mediated processes, rather than seeking potentially controversial legal means for procuring more water during the summer months.

Adaptation to future changes on the river, driven by climate change, population growth, and corresponding shifts in water use, will likely be addressed through collaboration with watershed stakeholders. To date, building collaborative capacity has involved working with the state (UDWRi), lower Bear River water users, and Bear River watershed conservation groups. During the adjudication of the lower Bear River, refuge managers worked extensively with UDWRi to file diligence claims on water for the refuge, purchase water rights with new lands, and obtain recognition for their quantified water need. Managers continue to communicate with the state when protesting new water rights applications that would inhibit their ability to meet the beneficial use of their water rights. When assessing threats to their water, BRMBR managers confer with nearby users, including the Bear River Canal Company (the largest canal company in the area), PacifiCorp (which operates the hydroelectric dams on the Bear River), and other neighbors to determine how various developments would affect the lower Bear River region as a whole. Refuge managers also participate in annual water right allocation meetings; this participation secures them a seat at the negotiating table and promotes sharing knowledge about the river system, even if it does not result in additional water for the refuge. BRMBR managers are currently leading efforts to create a watershed-wide Bear River Conservation Area with the goal of protecting habitat along the entire river (U.S. Fish and Wildlife Service 2013). These watershed conservation efforts aim to protect riparian corridors by securing voluntary agricultural land conservation easements and preventing water rights transfers that would take water outside the watershed. Education programs and research projects at the refuge also are encouraged and supported to build community interest in the refuge wetlands.

The collaboration and AM described here works well for a refuge in an agriculture-dominated landscape, but BRMBR is located at the shifting nexus of agricultural and urban water use that may ultimately result in less water in the Bear River, especially during the growing season. This shift is illustrated best by the Bear River Development Act, passed by the Utah State Legislature in 1991. The Act directs the Utah Division of Water Resources to develop $4.1 \times 10^{8} \mathrm{~m}^{3}(330,000 \mathrm{acft})$ of Bear River water that currently flows into the GSL (through the refuge) to support growing metropolitan areas in the state. Development of Bear River water threatens the GSL because there are no rights to protect water for the lake. Climate change will likely decrease water in the Bear River through increased water loss due to higher temperatures and decreased snowpack. It is uncertain how much the Bear River's hydrology will change or how wetlands will respond to changes in temperature and water supply, but as the water user at the end of the Bear River, BRMBR managers must be able to adapt their wetland management to these increasingly fast-paced changes and sources of uncertainty or face the risk of losing internationally significant wetlands.

\section{DISCUSSION}

\section{Adaptation to challenges at a critical nexus in a social-ecological system}

BRMBR lies at a critical nexus within the GSL SES between lake and river ecosystems and shifting water and land uses. Management of the refuge must adapt to changing social, ecological, and hydrological conditions at this nexus, which presents threats from drought and flooding, and associated water right and management challenges. Much of BRMBR wetland habitat dries during the summer months, but may be inundated with hypersaline water during floods; both are detrimental to habitat. The wetland nexus in the Bear River-GSL delta also faces water supply threats as agricultural lands go out of production, changing the patterns of irrigation return flow that these wetlands now rely on during the summer. The refuge's association with the GSL presents additional hydrological vulnerability because the wetlands downstream of refuge boundaries have no rights, and water has been legislated to metropolitan areas outside the watershed. Shifts in land and water use also change the identity of collaborators that managers work with, the relationships managers have built, and the type of impacts wetlands face. To negotiate these uncertainties successfully, managers must adapt their management strategy from one based on management within an agriculture-dominated watershed to one that incorporates shifting water uses and addresses new challenges and opportunities for cooperation. The lessons from social and environmental outcomes of AM at BRMBR are widely applicable for AM practitioners in other arid regions, particularly those managing deltaic wetland complexes in the lower parts of watersheds that face similar threats as water supplies become scarcer (Bedford 2005, Coleman et al. 2008, Keddy et al. 2009).

\section{Lessons learned}

Three lessons can be learned from this case study about AM at the BRMBR within the GSL SES. The first lesson is that adaptation at a critical wetland nexus in an SES is an ongoing, rapidly evolving process. Shifting from agriculture-dominated to residential water-use regimes in an area highly affected by climate change will likely increase the frequency and magnitude of drought events and further fragment large wetland complexes (Barnett et al. 2008). Future wetland management will face 
increased hydrological dynamism and water scarcity, a greater diversity of stakeholders with which to negotiate and collaborate, and a general reduction in global ecosystem functions (Pringle 2001, Zedler and Kercher 2005). Adaptation to increased uncertainty about future water supplies will require sensitivity to the dynamics of linked ecological and social changes in SESs.

Agriculture has long been linked to wetland loss in many parts of the world, but there is increasing recognition that wetlands in arid regions are intrinsically tied to agricultural practices and that wetland management can be successful within the constraints and opportunities provided by these linkages (Peck and Lovvorn 2001, Eckles 2011, Sueltenfuss et al. 2013). This has been the case for BRMBR, where managers have acquired water rights and constructed infrastructure based around irrigation season demands and return flow in ways that make habitat production mimic crop production (Downard and Endter-Wada 2013, Welsh et al. 2013). However, strategies that are well-adapted to agriculture-dominated rivers and landscapes may prove inadequate for hydrological changes predicted for arid-region SESs. Population growth is pushing increased irrigation efficiency, and the conversion of agricultural lands to residential development is being accompanied by the transfer of agricultural water rights to municipalities. These shifts result in subsequent changes to water use from the flood-irrigation pattern of intense seasonal agricultural demand and significant amounts of return flow to urban use that is year-round and provides less return flow (Sabo et al. 2010, Grant et al. 2012). Social adaptations discussed below will prove critical to maintaining wetland resilience in the face of climate change and population growth.

The second lesson of this AM case study is that establishing clear management strategies is a critical step in pursuing adaptive wetland management and protecting wetland water supplies. Defining clear management objectives based on bird use and water availability has been important at BRMBR in three ways: (1) It creates a metric (wildlife habitat) for establishing wetland water needs and involvement in water right negotiations; (2) it provides a means to maintain wetland resilience during drought through forecasting and impoundment; and (3) it secures public support through knowledge sharing and incorporation of public values with participatory planning. Establishing wetland water needs based on meeting the beneficial use of wildlife production not only made wetland management more scientifically driven, it also gave managers a means for negotiating with water users by creating a way to talk about both ecosystem and human water needs (Richter et al. 2003, Carpenter et al. 2009). Goal-based habitat planning that specifies monitoring targets (e.g., area of submergent and emergent wetland types with specific target water levels for access by multiple bird guilds) is especially necessary for efficiently managing large wetland complexes that support many types of wildlife, where management decisions have potentially huge ecological consequences for the resilience of both the wetland and migratory wildlife populations (Young et al. 2006). BRMBR was one of the first wetland refuges in the United States to adopt the practice of long-term and short-term planning, which is now required throughout the refuge system in a formalized comprehensive conservation planning $(\mathrm{CCP})$ process. The CCP process requires soliciting public input and incorporating the latest scientific information, including climate change projections, into refuge plans (U.S. Code 1997, Archie et al. 2012). Collaboration through local and regional planning processes as well as outreach efforts have proven crucial in gaining public trust and building collaborative capacity within other regions that are also facing changes to river hydrology (Olsson et al. 2004, Huitema et al. 2009).

The final lesson is that AM requires continually learning from both the social and ecological impacts of management decisions, particularly in transitioning SESs, where rapid changes require continual planning adjustments due to unpredicted circumstances (Pahl-Wostl et al. 2007). Although monitoring ecological responses has been an important facet of wetland management to date, future adaptations will require learning from the ways that social systems have responded to various constituencies' efforts to acquire and manage water supplies. Actions that create distrust within the community of water users make wetland management more politically difficult, even when legally appropriate, especially under conditions of water scarcity, when the linkages between users are tighter (Jackson et al. 2009). Managing for resilience of the region or watershed (as opposed to management within jurisdictional boundaries) may be the best option for future wetland management under changing water supplies (Cross et al. 2013). The ability to identify collaborators and find ways to work toward protecting regional water supplies is an important strategy for climate change adaptation as wetland managers try to expand their management horizon to anticipate and influence effects that happen outside their boundaries (PahlWostl 2006). Managers at BRMBR have pursued this strategy through their participation in water rights negotiation processes and communication with local land user groups with the intention of protecting the refuge's water supply and the resilience of its wetlands in the face of climate change and population growth.

\section{Conclusions}

This case study of wetland management at BRMBR demonstrates AM that is well suited to an agriculture-dominated river and identifies the changes required to meet the challenges of management under increasing uncertainty due to population growth and climate change. BRMBR managers actively manage water through acquisition of water rights, forecasting water supply and demand, impounding and diverting water when it is available, and monitoring habitat productivity and wildlife use of variously inundated areas. Here, reliance on irrigation return flow during periods of drought has led managers to communicate and collaborate with upstream water users to protect the water supply of the region as a whole. This process of managing a wetland nexus within an SES has not been without controversy, and managers have had to learn from both successes and mistakes in adapting to a changing context within which the refuge is located. Future AM will require the ability to respond quickly to changes in both ecological and social dimensions of the system. Appropriate responses will require extensive knowledge sharing among users of the entire river. To protect the resilience of complex SESs, managers will need to grapple with increasingly uncertain water supplies, but learning about the linkages among ecosystems, hydrology, and society can guide such efforts.

Responses to this article can be read online at: http://www.ecologyandsociety.org/issues/responses. $\mathrm{php} / 6412$ 


\section{Acknowledgments:}

The authors thank the people in the Bear River basin who were interviewed and provided information for this research. They are also grateful for support and feedback from Lisa Welsh and Judith Kurtzman and for assistance from the Special Collections and Archives and the Quinney Natural Resources Library at Utah State University. This project was supported by the USDA-CREES Utah Drought Management Project, awards 2008-34552-19042 and 2009-34552-19746; and by the Utah Agricultural Experiment Station, Utah State University, Projects UTAO1120 and UTAO1077. This paper was approved as journal paper 8663.

\section{LITERATURE CITED}

Acreman, M. C., J. R. Blake, D. J. Booker, R. J. Harding, N. Reynard, J. O. Mountford, and C. J. Stratford. 2009. A simple framework for evaluating regional wetland ecohydrological response to climate change with case studies from Great Britain. Ecohydrology 2(1):1-17. http://dx.doi.org/10.1002/eco.37

Adler, R. W. 2005. The law at the water's edge: limits to "ownership" of aquatic ecosystems. Pages 201-269 in C. A. Craig, editor. Wet growth: Should water law control land use? Environmental Law Institute, Washington, D.C., USA.

Aldrich, T. W., and D. S. Paul. 2002. Avian ecology of the Great Salt Lake. Pages 343-374 in J. W. Gwynn, editor. Great Salt Lake: a portrait of change. Utah Department of Natural Resources, Salt Lake City, Utah, USA.

Allen, C. R., J. J. Fontaine, K. L. Pope, and A. S. Garmestani. 2011. Adaptive management for a turbulent future. Journal of Environmental Management 92(5):1339-1345. http://dx.doi. org/10.1016/j.jenvman.2010.11.019

Anderies, J. M., M. A. Janssen, and E. Ostrom. 2004. A framework to analyze the robustness of social-ecological systems from an institutional perspective. Ecology and Society 9(1): 18. [online] URL: http://www.ecologyandsociety.org/vo19/iss1/art18/.

Archie, K. M., L. Dilling, J. B. Milford, and F. C. Pampel. 2012. Climate change and western public lands: a survey of U.S. federal land managers on the status of adaptation efforts. Ecology and Society 17(4): 20. http://dx.doi.org/10.5751/es-05187-170420

Barnett, T. P., D. W. Pierce, H. G. Hidalgo, C. Bonfils, B. D. Santer, T. Das, G. Bala, A. W. Wood, T. Nozawa, A. A. Mirin, D. R. Cayan, and M. D. Dettinger. 2008. Human-induced changes in the hydrology of the western United States. Science 319:1080-1083. http://dx.doi.org/10.1126/science.1152538

Bedford, D. 2005. Utah's Great Salt Lake: a complex environmental-societal system. Geographical Review 95(1):73-96. http://dx.doi.org/10.1111/j.1931-0846.2005.tb00192.x

Berkes, F., and C. Folke, editors. 1998. Linking social and ecological systems: management practices and social mechanisms for building resilience. Cambridge University Press, Cambridge, UK.

Brinson, M. M., and S. D. Eckles. 2011. U.S. Department of Agriculture conservation program and practice effects on wetland ecosystem services: a synthesis. Ecological Applications 21:S116S127. http://dx.doi.org/10.1890/09-0627.1
Brugnach, M., A. Dewulf, C. Pahl-Wostl, and T. Taillieu. 2008. Toward a relational concept of uncertainty: about knowing too little, knowing too differently, and accepting not to know. Ecology and Society 13(2): 30. [online] URL: http://www.ecologyandsociety. org/vol13/iss $2 / \operatorname{art} 30 /$.

Bunn, S. E., and A. H. Arthington. 2002. Basic principles and ecological consequences of altered flow regimes for aquatic diversity. Environmental Management 30(4):492-507. http://dx. doi.org/10.1007/s00267-002-2737-0

Carpenter, S. R., H. A. Mooney, J. Agard, D. Capistrano, R. S. DeFries, S. Díaz, T. Dietz, A. K. Duraiappah, A. Oteng-Yeboah, H. M. Pereira, C. Perrings, W. V. Reid, J. Sarukhan, R. J. Scholes, and A. Whyte. 2009. Science for managing ecosystem services: beyond the Millennium Ecosystem Assessment. Proceedings of the National Academy of Sciences 106(5):1305-1312. http://dx. doi.org/10.1073/pnas.0808772106

Christiansen, J. E., and J. B. Low. 1970. Water requirements of waterfowlmarshlands in northern Utah. Utah Division of Fish and Game, Salt Lake City, Utah, USA.

Coleman, J. M., O. K. Huh, and D. Braud Jr. 2008. Wetland loss in world deltas. Journal of Coastal Research 24(1A):1-14. http:// dx.doi.org/10.2112/05-0607.1

Cross, M. S., P. D. McCarthy, G. Garfin, D. Gori, and C. A. F. Enquist. 2013. Accelerating adaptation of natural resource management to address climate change. Conservation Biology 27 (1):4-13. http://dx.doi.org/10.1111/j.1523-1739.2012.01954.x

Dahl, T. E. 2011. Status and trends of wetlands in the conterminous United States 2004 to 2009. U.S. Fish and Wildlife Service, Washington, D.C., USA. [online] URL: http://www.fws.gov/ Wetlands/Documents/Status-and-Trends-of-Wetlands-in-theConterminous-United-States-2004-to-2009.pdf.

Denton, C. 2007. Bear River: last chance to change course. Utah State University Press, Logan, Utah, USA.

Downard, R., and J. Endter-Wada. 2013. Keeping wetlands wet in the western United States: adaptations to drought in agriculture-dominated human-natural systems. Journal of Environmental Management 131:394-406. http://dx.doi.org/10.1016/ j.jenvman.2013.10.008

Duffy, W. G., and S. N. Kahara. 2011. Wetland ecosystem services in California's Central Valley and implications for the Wetland Reserve Program. Ecological Applications 21:S18-S30. http://dx. doi.org/10.1890/09-1338.1

Eckles, S. D. 2011. Linking science, policy, and management to conserve wetlands in agricultural landscapes. Ecological Applications 21:S1-S2. http://dx.doi.org/10.1890/09-0506.1

Endter-Wada, J., and D. J. Blahna. 2011. Linkages to Public Land Famework: toward embedding humans in ecosystem analyses by using "inside-out social assessment". Ecological Applications 21 (8):3254-3271. http://dx.doi.org/10.1890/10-2392.1

Endter-Wada, J., T. Selfa, and L. W. Welsh. 2009. Hydrologic interdependencies and human cooperation: the process of adapting to droughts. Weather, Climate, and Society 1(1):54-70. http://dx.doi.org/ doi:10.1175/2009WCAS1009.1 
Erwin, K. L. 2009. Wetlands and global climate change: the role of wetland restoration in a changing world. Wetlands Ecology and Management 17(1):71-84. http://dx.doi.org/10.1007/s11273-008-9119-1

Euliss, N. H., L. M. Smith, D. A. Wilcox, and B. A. Browne. 2008. Linking ecosystem processes with wetland management goals: charting a course for a sustainable future. Wetlands 28(3):553-562. http://dx.doi.org/10.1672/07-154.1

Evans, K., and W. Martinson. 2008. Utah's featured birds and viewing sites: a conservation platform for IBAs and BHCAs. Utah Department of Natural Resources, Salt Lake City, Utah, USA.

Falkenmark, M. 2013. Adapting to climate change: towards societal water security in dry-climate countries. International Journal of Water Resources Development 29(2):123-136. http://dx. doi.org/10.1080/07900627.2012.721714

Folke, C. 2006. Resilience: the emergence of a perspective for social-ecological systems analyses. Global Environmental Change 16(3):253-267. http://dx.doi.org/10.1016/j.gloenvcha.2006.04.002

Gordon, L. J., C. M. Finlayson, and M. Falkenmark. 2010. Managing water in agriculture for food production and other ecosystem services. Agricultural Water Management 97 (4):512-519. http://dx.doi.org/10.1016/j.agwat.2009.03.017

Grant, S. B., J.-D. Saphores, D. L. Feldman, A. J. Hamilton, T. D. Fletcher, P. L. M. Cook, M. Stewardson, B. F. Sanders, L. A. Levin, R. F. Ambrose, A. Deletic, R. Brown, S. C. Jiang, D. Rosso, W. J. Cooper, and I. Marusic. 2012. Taking the "waste" out of "wastewater" for human water security and ecosystem sustainability. Science 337(6095):681-686. http://dx.doi.org/10.1126/ science. 1216852

Gunderson, L. 1999. Resilience, flexibility and adaptive management - antidotes for spurious certitude? Conservation Ecology 3(1): 7. [online] URL: http://www.consecol.org/vol3/iss1/ art7l.

Gunderson, L. H., S. R. Carpenter, C. Folke, P. Olsson, and G. Peterson. 2006. Water RATs (resilience, adaptability, and transformability) in lake and wetland social-ecological systems. Ecology and Society 11(1): 16. [online] URL: http://www. ecologyandsociety.org/vol11/iss1/art16/.

Hahn, T., P. Olsson, C. Folke, and K. Johansson. 2006. Trustbuilding, knowledge generation and organizational innovations: the role of bridging organization for adaptive comanagement of a wetland landscape around Kristianstad, Sweden. Human Ecology 34(4):573-592. http://dx.doi.org/10.1007/s10745-006-9035$\underline{z}$

Holling, C. S. 1978. Adaptive environmental assessment and management. Wiley, London, UK.

Huitema, D., E. Mostert, W. Egas, S. Moellenkamp, C. PahlWostl, and R. Yalcin. 2009. Adaptive water governance: assessing the institutional prescriptions of adaptive (co-)management from a governance perspective and defining a research agenda. Ecology and Society 14(1): 26. [online] URL: http://www.ecologyandsociety. org/vol14/iss1/art26/.

Ivey, G. L., and C. P. Herziger. 2006. Intermountain West waterbird conservation plan, version 1.2. A plan associated with the Waterbird Conservation for the Americas Initiative. U. S. Fish and Wildlife
Service, Portland, Oregon, USA. [online] URL: http://www.fws. gov/pacific/migratorybirds/PDF/IWWCP.pdf.

Jackson, R. B., S. R. Carpenter, C. N. Dahm, D. M. McKnight, R. J. Naiman, S. L. Postel, and S. W. Running. 2001. Water in a changing world. Ecological Applications 11(4):1027-1045. http:// dx.doi.org/10.1890/1051-0761(2001)011[1027:WIACW]2.0.CO;2

Jackson, R. B., E. G. Jobbágy, and M. D. Nosetto. 2009. Ecohydrology in a human-dominated landscape. Ecohydrology 2 (3):383-389. http://dx.doi.org/10.1002/eco.81

Jin, J., S.-Y. Wang, and R. R. Gillies. 2011. An improved dynamical downscaling for the western United States. Pages 23-38 in J. Blanco and $\mathrm{H}$. Kheradmand, editors. Climate change: research and technology for adaptation and mitigation. InTech, Rijeka, Croatia. [online] URL: http://cdn.intechopen.com/ pdfs/18711/InTech-An improved dynamical downscaling for the western united states.pdf.

Keddy, P. A., L. H. Fraser, A. I. Solomeshch, W. J. Junk, D. R. Campbell, M. T. K. Arroyo, and C. J. R. Alho. 2009. Wet and wonderful: The world's largest wetlands are conservation priorities. Bioscience 59(1):39-51. http://dx.doi.org/10.1525/ bio.2009.59.1.8

Knapp, A. K., C. Beier, D. D. Briske, A. T. Classen, Y. Luo, M. Reichstein, M. D. Smith, S. D. Smith, J. E. Bell, P. A. Fay, J. L. Heisler, S. W. Leavitt, R. Sherry, B. Smith, and E. Weng. 2008. Consequences of more extreme precipitation regimes for terrestrial ecosystems. Bioscience 58(9):811-821. http://dx.doi. org/10.1641/b580908

Lemly, A. D., R. T. Kingsford, and J. R. Thompson. 2000. Irrigated agriculture and wildlife conservation: conflict on a global scale. Environmental Management 25(5):485-512. http://dx. doi.org/10.1007/s002679910039

Lundquist, J. D., M. D. Dettinger, I. T. Stewart, and D. R. Cayan. 2009. Variability and trends in spring runoff in the western United States. Pages 63-76 in F. Wagner, editor. Climate warming in western North America: evidence and environmental effects. University of Utah Press, Salt Lake City, Utah, USA.

Mitsch, W. J., and J. G. Gosselink. 2007. Wetlands. Fourth edition. Wiley, Hoboken, New Jersey, USA.

Mote, P. W. 2009. Variability and trends in mountain snowpacks in western North America. Pages 51-62 in F. Wagner, editor. Climate warming in North America: evidence and environmental effects. University of Utah Press, Salt Lake City, Utah, USA.

Oki, T., and S. Kanae. 2006. Global hydrological cycles and world water resources. Science 313(5790):1068-1072. http://dx.doi. org/10.1126/science.1128845

Olson, B. 2006. Annual habitat management plan 2006: Bear River Migratory Bird Refuge. U.S. Fish and Wildlife Service, Brigham City, Utah, USA. [online] URL: http://utah.ptfs.com/awweb/ awarchive? type $=$ file \&item $=20562$.

Olson, B. 2007. Annual habitat management plan 2007: Bear River Migratory Bird Refuge. U.S. Fish and Wildlife Service, Brigham City, Utah, USA. [online] URL: http://utah.ptfs.com/awweb/ guest.jsp?smd=1!cl=all lib\&lb document id=20563. 
Olson, B. 2008. Annual habitat management plan 2008: Bear River Migratory Bird Refuge. U.S. Fish and Wildlife Service, Brigham City, Utah, USA. [online] URL: http://utah.ptfs.com/awweb/ awarchive? type $=$ file \&item $=20564$.

Olson, B. 2009. Annual habitat management plan 2009: Bear River Migratory Bird Refuge. U.S. Fish and Wildlife Service, Brigham City, Utah, USA. [online] URL: http://utah.ptfs.com/awweb/ awarchive? type $=$ file\&item $=20565$.

Olson, B. E., K. Lindsey, and V. Hirschboeck. 2004. Habitat management plan: Bear River Migratory Bird Refuge. U.S. Fish and Wildlife Service, Brigham City, Utah, USA. [online] URL: http://www.fws.gov/uploadedFiles/BR HMP.pdf.

Olsson, P., C. Folke, and T. Hahn. 2004. Social-ecological transformation for ecosystem management: the development of adaptive co-management of a wetland landscape in southern Sweden. Ecology and Society 9(4): 2. [online] URL: http://www. ecologyandsociety.org/vol9/iss4/art2.

Pahl-Wostl, C. 2006. The importance of social learning in restoring the multifunctionality of rivers and floodplains. Ecology and Society 11(1): 10. [online] URL: http://www.ecologyandsociety. org/vol11/iss 1/art10/.

Pahl-Wostl, C., M. Craps, A. Dewulf, E. Mostert, D. Tabara, and T. Taillieu. 2007. Social learning and water resources management. Ecology and Society 12(2): 5. [online] URL: http:// www.ecologyandsociety.org/vol12/iss2/art5/.

Peck, D. E., and J. R. Lovvorn. 2001. The importance of flood irrigation in water supply to wetlands in the Laramie Basin, Wyoming, USA. Wetlands 21(3):370-378. http://dx.doi. org/10.1672/0277-5212(2001)021[0370:tiofii]2.0.co;2

Peck, D. E., D. M. McLeod, J. P. Hewlett, and J. R. Lovvorn. 2004. Irrigation-dependent wetlands versus instream flow enhancement: economics of water transfers from agriculture to wildlife uses. Environmental Management 34(6):842-855. http:// dx.doi.org/10.1007/s00267-004-3085-Z

Poff, N. L., J. D. Olden, D. M. Merritt, and D. M. Pepin. 2007. Homogenization of regional river dynamics by dams and global biodiversity implications. Proceedings of the National Academy of Sciences 104(14):5732-5737. http://dx.doi.org/10.1073/ pnas.0609812104

Porzecanski, I., L. V. Saunders, and M. T. Brown. 2012. Adaptive management fitness of watersheds. Ecology and Society 17(3): 29. http://dx.doi.org/10.5751/es-05061-170329

Postel, S. L. 2000. Entering an era of water scarcity: the challenges ahead. Ecological Applications 10(4):941-948. http://dx.doi. org/10.2307/2641009

Pringle, C. M. 2001. Hydrologic connectivity and the management of biological reserves: a global perspective. Ecological Applications 11(4):981-998. http://dx.doi.org/10.1890/1051-0761 (2001)011[0981:HCATMO]2.0.CO:2

Richter, B. D., R. Mathews, D. L. Harrison, and R. Wigington. 2003. Ecologically sustainable water management: managing river flows for ecological integrity. Ecological Applications 13 (1):206-224. http://dx.doi.org/10.1890/1051-0761(2003)013[0206: ESWMMR]2.0.CO;2
Sabo, J. L., T. Sinha, L. C. Bowling, G. H. W. Schoups, W. W. Wallender, M. E. Campana, K. A. Cherkauer, P. L. Fuller, W. L. Graf, J. W. Hopmans, J. S. Kominoski, C. Taylor, S. W. Trimble, R. H. Webb, and E. E. Wohl. 2010. Reclaiming freshwater sustainability in the Cadillac Desert. Proceedings of the National Academy of Sciences 107(50):21263-21269. http://dx.doi. org/10.1073/pnas.1009734108

Smith, L. M., N. H. Euliss Jr., D. A. Wilcox, and M. M. Brinson. 2008. Application of a geomorphic and temporal perspective to wetland management in North America. Wetlands 28(3):563-577. http://dx.doi.org/10.1672/07-155.1

Sueltenfuss, J. P., D. J. Cooper, R. L. Knight, and R. M. Waskom. 2013. The creation and maintenance of wetland ecosystems from irrigation canal and reservoir seepage in a semi-arid landscape. Wetlands 33(5):799-801. http://dx.doi.org/10.1007/s13157-013-0437-6

Tiner, R. W. 2003. Geographically isolated wetlands of the United States. Wetlands 23(3):494-516. http://dx.doi.org/10.1672/0277-5212 (2003)023[0494:GIWOTU]2.0.CO:2

U.S. Code. 1997. National Wildlife Refuge System Improvement Act of 1997, 16 U.S.C. 668dd. (Public Law 105-57-Oct. 9, 1997; 111 STAT. 1252). U.S. Government, Washington, D.C., USA.

U.S. Fish and Wildlife Service. 2013. Land protection plan: Bear River Watershed Conservation Area: Idaho, Utah, and Wyoming. U.S. Fish and Wildlife Service, Regions 1 and 6, Lakewood, Colorado, USA. [online] URL: https://www.fws.gov/mountainprairie/planning/lpp/ut/brr/documents/brw lpp final all.pdf.

U.S. Geological Survey. 2014. National water information system: USGS 1012600 Bear River near Corinne, UT. U.S. Geological Survey, Washington, D.C., USA. [online] URL: http://waterdata. usgs.gov/nwis/inventory?agency code $=$ USGS!site no=10126000.

Utah Division of Water Resources. 2004. Bear River Basin: planning for the future. Utah Division of Water Resources, Salt Lake City, Utah, USA. [online] URL: http://water.utah.gov/ Planning/SWP/bear/bearRiver-1A.pdf.

Utah Division of Water Rights. 2005. In the matter of the general determination of the rights to the use of all the water, both surface and underground, within the drainage area of the Bear River and all of its tributaries in Utah: Box Elder County Division - Bear River Bay Subdivision. State Engineer of the State of Utah, Logan, Utah, USA. [online] URL: http://waterrights.utah.gov/docSys/ v910/d910/d91004ax.pdf.

Utah Division of Water Rights. 2011. Water right information. Utah Division of Water Rights, Logan, Utah, USA. [online] URL: http://www.waterrights.utah.gov/wrinfo/default.asp.

Utah Water Research Laboratory. 2012. Bear River watershed information system. Utah State University, Logan, Utah, USA. [online] URL: http://www.bearriverinfo.org.

Walker, B., S. Carpenter, J. Anderies, N. Abel, G. S. Cumming, M. Janssen, L. Lebel, J. Norberg, G. D. Peterson, and R. Pritchard. 2002. Resilience management in social-ecological systems: a working hypothesis for a participatory approach. Conservation Ecology 6(1): 14. [online] URL: http://www. consecol.org/vol6/iss1/art14. 
Walker, B., C. S. Holling, S. R. Carpenter, and A. Kinzig. 2004. Resilience, adaptability and transformability in social-ecological systems. Ecology and Society 9(2): 5. [online] URL: http://www. ecologyandsociety.org/vo19/iss2/art5.

Walker, B., and J. A. Meyers. 2004. Thresholds in ecological and social-ecological systems: a developing database. Ecology and Society 9(2): 3. [online] URL: http://www.ecologyandsociety.org/ vol9/iss $2 /$ art3.

Welsh, L. W., J. Endter-Wada, R. Downard, and K. M. Kettenring. 2013. Developing adaptive capacity to droughts: the rationality of locality. Ecology and Society 18(2): 7. http://dx.doi. org/10.5751/ES-05484-180207

Young, O. R., E. F. Lambin, F. Alcock, H. Haberl, S. I. Karlsson, W. J. McConnell, T. Myint, C. Pahl-Wostl, C. Polsky, P. S. Ramakrishnan, H. Schroeder, M. Scouvart, and P. H. Verburg. 2006. A portfolio approach to analyzing complex humanenvironment interactions: institutions and land change. Ecology and Society 11(2): 31. [online] URL: http://www.ecologyandsociety. org/vol11/iss2/art31/.

Zedler, J. B., J. M. Doherty, and N. A. Miller. 2012. Shifting restoration policy to address landscape change, novel ecosystems, and monitoring. Ecology and Society 17(4): 36. http://dx.doi. org/10.5751/ES-05197-170436

Zedler, J. B., and S. Kercher. 2005. Wetland resources: status, trends, ecosystem services, and restorability. Annual Review of Environmental Resources 30:39-74. http://dx.doi.org/10.1146/ annurev.energy.30.050504.144248 
Appendix 1. Questions used to guide semi-structured key-informant interviews conducted in 2009 and 2010 and interview participants.

\section{Questions}

1. Where does the water come from that maintains ("Bear River" or specific reference) wetlands?

Probes: Do (these) wetlands have certificated water rights? If so, what is the nature of those rights? If not, how is the water secured?

2. How much water, in terms of amount and frequency, do these wetlands need?

3. What happens to ("Bear River" or specific reference) wetlands in times of drought?

4. Is maintenance of ("Bear River" or "these") wetlands controversial? Can you explain? Probes: What groups or individuals are involved in this controversy?

5. What are the constraints to obtaining enough water to maintain these wetlands? Probes: What constraints operate on an annual basis? What constraints pertain in times of scarcity?

6. What are the opportunities for obtaining enough water to maintain these wetlands? Probes: What is the role of formal water rights applications? What is the role of informal agreements?

7. How do natural resource agencies take wetlands into account in their planning processes?

8. How does your state division of water rights take wetlands into account when reviewing water use applications (e.g. applications for new appropriations or changes of use)?

9. I would be interested in hearing your opinions about wetland policies.

Probes: What do you think are the strengths and weaknesses of those policies?

10. Do the policies and politics differ depending upon the geographic location of the wetland involved? Can you explain?

\section{Interview Participants}

U.S. Fish and Wildlife Service

Bear River Migratory Bird Refuge Managers (2)

Bear River Migratory Bird Refuge Biologist

Bear Lake National Wildlife Refuge Manager

Cokeville Meadows National Wildlife Refuge Manager

U.S. Environmental Protection Agency

Wetlands Liason

State of Utah 
State Engineer's Office Northern Division Managers (2)

Utah Division of Wildlife Resources Habitat Biologist

Utah Division of Wildlife Resources Water Rights Specialist 